\title{
Books
}

\section{The railway} metropolis

- how planners, politicians and developers shaped modern London

by Michael Schabas, published by ICE Publishing, 2017, £31.50, reviewed by

Stuart Ross, Arup, UK

The book is a fascinating read for all who use or are involved in the railways, particularly civil engineers. As London's Crossrail project reaches completion, the book provides a useful reference of past successes and failures when considering the future of the UK capital's vital public transportation network.

The book describes the development of London's railways from World War II, with detailed accounts of High Speed One, Docklands Light Railway, Jubilee line extension, London Overground, Thameslink and Crossrail.

The interface of the city's railways with an ever-changing political climate, plus comprehensive technical details and good use of graphics and photographs, ensures a complete picture of how the network has developed. The book also describes some of the abandoned ideas and schemes that never made it to the stage of breaking ground.

Although there is a focus on London, many of the issues and challenges described will apply to cities across the globe. Overall it is an extremely enjoyable read and one that can be recommended to construction industry professionals and anyone with a general interest in railways.

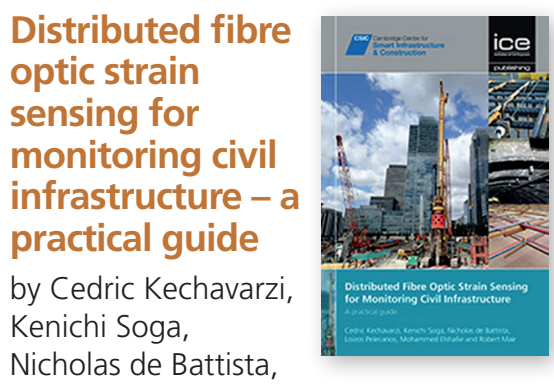

Loizos Pelecanos, Mohammed Elshafie and Robert Mair, 2016, published by ICE Publishing $₫ 45 \cdot 50$, reviewed by Jamie

Radford, Mott MacDonald, UK

This is a comprehensive guide to the use of distributed fibre-optic strain sensing and how it can improve understanding of a civil engineering structure's performance through structural health and integrity monitoring and performance-based design.

It starts with an overview of the physical principles followed by practical considerations for planning and designing a system. Installation advice is provided, with photographs of how cables can be embedded in reinforced concrete, bonded to structural sections or attached to existing structures at discrete points. Analysis and interpretation of the data are explained for piles, retaining walls, tunnels and embankment slopes.

The second half of the guide has 100 pages of case studies of flagship projects, ranging from London's Crossrail to Singapore's MRT.

Overall, it provides a thorough introduction to the capabilities, applications and limitations of distributed fibre-optic strain sensing. It will be relevant to many practising civil engineers, particularly for better understanding the performance of geotechnical structures.

\section{Structural analysis}

by Mikus Cirulis and Phil Wicks, published by ICE Publishing, 2015, f31, reviewed

\section{by Emma Kent,}

Cundall, UK

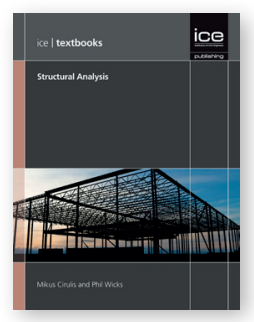

This undergraduate guide focuses on the application of structural theories to practical examples of structural scenarios that practising engineers may encounter.

The book assumes understanding of some advanced mathematics, physics and materials concepts such as axial, shear and bending actions, stress and strain, elastic and plastic behaviour and so on. As such it might be better suited to the second- or third-year undergraduate who has already developed understanding of the fundamentals of engineering from their first-year studies.

The principle of the book is to elaborate on the theory, techniques and methods which underpin the fundamentals of structural engineering and computer-based structural analysis. This allows the student to understand the appropriate inputs, expected structural behaviours and verification of outputs from a finite-element model.

The penultimate chapter is particularly beneficial as it focuses on developing the engineering judgement qualitatively to understand and visualise the predicted behaviour of a structure, which allows for a rapid validation of a numerical or computer-based assessment.

The book is clearly laid out and easy to follow. It would be a useful resource for structural engineering undergraduates and a handy reference for design offices as well.

\section{Geotechnical finite element analysis - a practical guide by Andrew Lees, published by ICE Publishing, $\mathrm{f49}$, 2016, reviewed by Colin Rawlings, High Speed 2, UK}

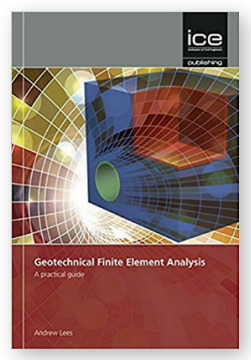

This 274-page book provides guidance and detailed explanations of applying finite-element analysis in geotechnical design.

It covers setting up a geotechnical model, selecting constitutive models, obtaining soil and rock parameters, accounting for groundwater effects, modelling geotechnical structures, using with design codes and assessing accuracy of outputs. The final chapter provides examples for a raft foundation with settlement-reducing piles, a shaft excavation and an embankment. 
The book will provide a useful reference for civil engineers who do not carry out finite-element analysis full time. It offers the necessary background or refresher information to improve their competence when reviewing the results of a geotechnical finite-element analysis for a civil engineering project.

The ICE Library maintains one of the most comprehensive collections of civil engineering books in the world, including all titles from ICE Publishing (shown in bold below). New books received in the past 3 months include the following.

\begin{tabular}{|c|c|c|}
\hline A practical guide to successful construction projects & A Van Wassenaer & $f 140 \cdot 00$ \\
\hline Alkali-aggregate reaction in concrete: a world review & A Poole and I Sims & f170.00 \\
\hline Back analysis in rock engineering & S Sakurai & f125.00 \\
\hline Chief engineer: the man who built the Brooklyn Bridge & E Wagner & $\mathrm{f} 25 \cdot 00$ \\
\hline Civil engineering structures according to the Eurocodes: inspection and maintenance & X Lauzin & £120.00 \\
\hline Clients and users in construction: agency, governance and innovation & K Haugbolle and D Boyd & f95.00 \\
\hline Community energy: a guide to community-based renewable-energy projects & G Cowtan & f19.99 \\
\hline Concrete industrial ground floors - user expectation & Concrete Society & $\mathrm{f} 10 \cdot 00$ \\
\hline Cool cities: urban sovereignty and the fix for global warming & B Barber & f16.99 \\
\hline Crack width measurement & Concrete Society & $f 8.00$ \\
\hline Cultivated building materials: industrialized natural resources for architecture and construction & D Hebel and F Heisel & $\mathrm{f} 60 \cdot 00$ \\
\hline Design companion for planning and placemaking & Transport for London & f30.00 \\
\hline Durability of concrete: design and construction & M Alexander et al. & f129.99 \\
\hline Energy storage in power systems & F Diaz-Gonzalez et al. & $f 81 \cdot 50$ \\
\hline Geoenvironmental practices and sustainability: linkages and directions & G Babu et al. & $f 112 \cdot 00$ \\
\hline Ground remediation: a practical guide for environmental engineers and scientists & N Cheremisinoff & $f 200 \cdot 00$ \\
\hline Innovative earthquake soil dynamics & T Kokusho & $£ 100 \cdot 00$ \\
\hline Integrated coastal zone management: status, challenges and prospects & F Ahlhorn & f57.99 \\
\hline Introduction to earthquake engineering & H Estrada and L Lee & f76.99 \\
\hline Large volume concrete pours & Concrete Society & $f 10 \cdot 00$ \\
\hline Major infrastructure projects: planning for delivery & E Ochieng et al. & f41.99 \\
\hline Modeling steel and composite structures & P Vellasco & $\mathrm{f} 91.00$ \\
\hline Progressive collapse analysis of structures: numerical codes and applications & D Isobe & f118.00 \\
\hline Railway bridge maintenance ( 2 nd ed.) & N Ricketts & $\mathrm{f} 65.00$ \\
\hline Reconnecting people and water: public engagement and sustainable urban water management & L Sharp & f34.99 \\
\hline Rethinking masterplanning: creating quality places & H AlWaer and B Illsley & $\mathbf{f} 60.00$ \\
\hline Scaffolds and falsework: constructions, structural design, assessment & R Hertle & $\mathrm{f} 60 \cdot 00$ \\
\hline Smart cities: foundations, principles, and applications & H Song et al. & $f 105 \cdot 60$ \\
\hline Storing energy: with special reference to renewable energy sources & T Letcher & $\mathrm{f} 85 \cdot 00$ \\
\hline Streetfight: handbook for an urban revolution & J Sadik-Khan and S Solomonow & f14.88 \\
\hline Structural use of hardwoods WIS 1-17 & Trada & $\mathrm{f} 12 \cdot 00$ \\
\hline Sustainable slope stabilization using recylced plastic pins & S Hossain et al. & f115.00 \\
\hline Tall building foundation design & H Poulos & f129.99 \\
\hline The essential engineer: why science alone will not solve our global problems & A Vesic and H Petroski & $f 12 \cdot 42$ \\
\hline The new Panama Canal: a breathtaking journey between the Pacific and Atlantic oceans & R Britton and E Montaina & $f 55 \cdot 00$ \\
\hline The provision of holes in reinforced concrete beams & Concrete Society & $f 10 \cdot 00$ \\
\hline Understanding rails and rail welding & Permanent Way Institution & f80.00 \\
\hline
\end{tabular}

